\title{
LOST A BoB But Found A TANNER: FROM A TRANSLATOR'S WORKSHOP
}

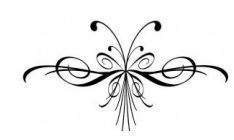

MARIANNA GULA

s Fritz Senn noted four decades ago, translators of Ulys-
ses embark upon "a veritable odyssey," so they need "the
skill, the resourcefulness of Odysseus himself, as well as his perseverance and, if possible, some help from a kindly disposed goddess of wisdom."1 What Senn's writings have amply demonstrated, however, is that no matter how endowed with the above mentioned merits translators are, the language of Ulysses ineluctably resists or evades their kindly efforts. As a Joyce scholar, I wholeheartedly subscribe to Senn's opinion that to translate Ulysses is to fail as no other literary translator dare fail. However, as a participant in a project launched and led by András Kappanyos (2003-2012), the aim of which is to provide a more satisfactory Hungarian version of Ulysses by thoroughly re-working Miklós Szentkuthy's 1974 translation $^{2}$ and creatively using Endre Gáspár's earlier 1947 translation where possible, ${ }^{3}$ I have been obliged for a while now to redirect my mental energies, to mute my scepticism and mobilise scholarly perspicacity in the name of the practical task at hand.

Thus, it is the perspective of the translator that will dominate my present inquiry. Much inspired by Senn's writings and being fully aware of the heavy losses that translating Ulysses inescapably entails, I will focus on the work of salvage, removal of debris, and the concomitant occasional gains. Since András Kappanyos, who conceived of the necessity of a partially new Hungarian translation in 1997, has already outlined the

\footnotetext{
${ }^{1}$ Fritz Senn, "Seven Against Ulysses," James Joyce Quarterly 4:3 (1967), p. 170.

2 James Joyce, Ulysses, trans. Szentkuthy Miklós (Budapest: Európa, 1974). Szenkuthy's translation was slightly modified by Tibor Bartos in 1986 (James Joyce, Ulysses, trans. Szentkuthy Miklós, ed. Bartos Tibor (Budapest: Európa, 1986). Our reworking of Szentkuthy's translation far exceeds Bartos's tampering with the text.

${ }^{3}$ James Joyce, Ulysses, trans. Gáspár Endre (Budapest: Nova Irodalmi Intézet. 1947, 2 vols).
} 
whys and wherefores of our collaborative effort elsewhere, ${ }^{4}$ here I will highlight one aspect of our work, probably the one of most importance to me personally: our endeavour to maximise the reader's opportunity to read with the sort of creative cooperation that Joyce's text allows, or rather, invites. As Senn has observed, translations in general tend to reduce such opportunities, ${ }^{5}$ since they "become more thing-oriented; the language as co-author recedes," they "curtail choices," severe links, ${ }^{6}$ they cannot "follow Joyce into all his allusive bypaths," fore "every one of [their] particles is less capable of an epiphany than those of the original."

In what follows I will try to give a taste of our grappling with this general tendency by applying a global method that could be described as transference of functions and effects. This means that we try to re-channel semantic, semiotic, stylistic and so forth potentials: if language as coauthor must recede in the Hungarian translation at numerous textual loci where it performs an awful lot of work in the original, then we make it perform more intensely in places where it is less epiphanic there. Our approach also entails that on occasions we modify the nature of the epiphany a textual particle is capable of. Likewise, if numerous structural links cannot be rendered in Hungarian at all, or only at the sweat of our brow, which could later be sensed by the reader, then instead of forcing them where they stand in the original, we try to introduce others elsewhere, where the effort itself becomes imperceptible. To the fair question whether we are still producing a translation at all the answer is in the positive, one hopes, since our creative 'meddling' with Joyce's text is humbly moderate and always emulates Joycean micro or macro verbal economy. I will demonstrate this by three examples.

\section{Homeric Shifting}

Joyce, the fabulous artificer, creates dedalian networks out of all kinds of words and phrases changing colour. Translators incessantly impair them, trying to make amends where possible. First, I will concentrate on the most conspicuous such instance, the "Throwaway" complex. It is

\footnotetext{
${ }^{4}$ András Kappanyos' more general article, a sort of report on our collective effort, will come out soon in the James Joyce Quarterly. Our collective interference with Miklós Szentkuthy's translation became much more radical than originally planned by Kappanyos in 1997.

${ }^{5}$ Senn, Joyce's Dislocutions: Essays on Reading as Translation, ed. John Riquelme (Baltimore and London: The Johns Hopkins University Press, 1984), p. 16.

${ }^{6}$ Ibid, p. 28.

${ }^{7}$ Senn, (1967), p. 184.

${ }^{8}$ Senn, (1984), p. 20.
} 
not the difficulties caused by the "rich exfoliation of the motif," as Senn has put it, that I want to dwell on. That it presents one of the thorniest problems for translators in general was thoroughly demonstrated by Senn four decades ago, and needs no further elaboration. ${ }^{9}$ What I will outline instead is how the impossibility of perfectly fusing even the most salient traits of the cluster in a Hungarian translation has been partially compensated for by the infusion of a richly exfoliating intertextual echo into it.

It is almost shameful to admit that up to now Hungarian readers of Ulysses has been left in the dark as to why Leopold Bloom is accused in "Cyclops" of betting on a horse and winning money on it, since both Gáspár and Szentkuthy sever the link between Bloom's words to Bantam Lyons at the end of "Lotus Eaters" - "I was just going to throw it away" ( $U$ 4.534) - and the horse's name "Throwaway" revealed in "Cyclops". ${ }^{10}$ Neither does Szentkuthy link either Bloom's words or the horse's name with the throwaway placed in Bloom's hands in "Lestrygonians" ( $U$ 8.6). Gáspár, by contrast, makes a clumsy effort to establish the former connection, which makes it all the more puzzling why he ignores the structurally indispensable link.

Thus, salvaging as much of the "Throwaway" complex as possible became a crucial task of our project. After racking our brains for a long time how to restore the connection between the three pivotal textual points, we managed to establish the indispensable link between Bloom's words and the horse's name in the following way: the horse's name has become Semmirekellö (an idiomatic adjective also used as a noun, which literally comes closest to "Good-for-nothing") - as good a name for a horse as Szentkuthy's "Többsincs" ('Nomore') - and Bloom's utterance has been rendered as "Nekem már úgysem kell semmire" (emphasis added), which roughly translates into 'I don't need it for anything' (courtesy of Kappanyos). Even though to a non-Hungarian eye semmirekellö may seem a far cry from kell semmire, to a Hungarian the connection is unmistakable. With a little shifting we have also managed to hint at the third pillar of the complex in "Lestrygonians", even though it is not one of our most elegant solutions. ${ }^{11}$ Our delight was further enhanced by my later

\footnotetext{
${ }^{9}$ See Senn (1967), pp. 179-81.

10 Kappanyos called attention to this problem in 1997. See his "Ulysses, a nyughatatlan." Átváltozások 10 (1997): 44-53.p. 49.

${ }^{11}$ We have translated the English sentence "A sombre Y. M. C. A. young man, watchful among the warm sweet fumes of Graham Lemon's, placed a throwaway in a hand of Mr Bloom" (U 8.5-6) as "Egy komor semmirekellö suhanc (Keresztény Ifjúsági Egyesület) lesben a Graham Lemon melegédes gőzében, szórólapot csúsztatott Mr. Bloom kezébe" (Emphases added). Since it was impossible to translate the English word "throwaway" in this context in a way that would have been reminiscent of the other two textual places, we have sneaked the horse's new name semmirekellö into the sentence in a roundabout way by translating "young man" as semmirekellö suhanc, literally meaning 'a good-for-nothing lad.' This evidently distorts the meaning in the
} 
discovery that the horse's new name Semmirekellö also introduces such particularly pertinent intertextual echoes into the text that are not present in the original.

By translating the horse's name "Throwaway" as Semmirekello one can establish a patent link with Gábor Devecseri's translation of the Odyssey, the par excellence Hungarian translation of Homer's epic..$^{12}$ Although the horse's name in the original may also evoke a Homeric scene, Polyphemus throwing rocks after Odysseus's ship, this echo is by far not as polyvalent as the one lurking in the Hungarian name. Semmirekellö conjures up a pivotal scene in the plot of the Odyssey - the scene that describes what provokes Polyhemus into throwing rocks - Odysseus's outwitting the Cyclops by the use of a false name Oṽ̃ı, translated as "Noman" in most English translations Joyce knew or was reported to have used while writing Ulysses, ${ }^{13}$ and as Senkise by Devecseri. Having been blinded by Noman, Polyphemus laments to his darling ram, going

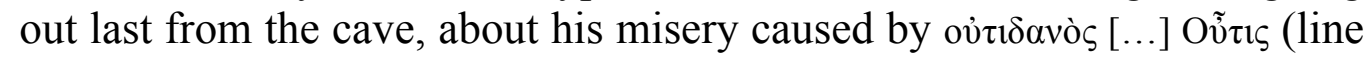
460)..$^{14}$ What Joyce's potential sources translate as "Outis, wretch basenamed and nothing worth" (Cowper), "vile Noman" (Pope), "no-good Noman" (Butler), "worthless No-man" (T. E. Shaw), and "Noman, nothing worth" (Butcher and Lang), Devecseri translates as semmirekellö Senkise, a masterful approximation of the Homeric Greek's figura etymologi$c a$, either totally missing from or less elegantly rendered by the English translations. Soon after this, the word oviı $\delta$ avòs (line 515) is used by Polyphemus a second time. On learning Odysseus's real name, he realises that an ancient prophecy has come upon him and recognises that it was his false expectations that deceived him: he was watching out for someone of "imposing presence and superhuman strength"15 but his destroyer has

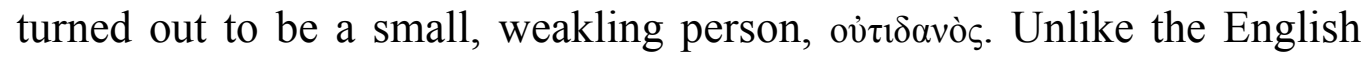
translations, which, with one exception, do not even try to link the two

original, since the Hungarian translation ascribes a judgemental edge to an entirely neutral phrase, yet, such a distortion does not cause any serious damage.

12 Homérosz, Odüsszeia, trans. Devecseri Gábor, 1947 (Budapest: Európa Kiadó, 1999).

${ }^{13}$ As Keri Elizabeth Ames has recently observed in a thoroughly researched article on what encounters Joyce had with Homer's Odyssey, beside his "untrained forays into Homeric Greek," Joyce read numerous translations of Homer at different times in his life. As an adolescent he cherished Charles Lamb's The Adventures of Ulysses, later studying it along with Pope's and Cowper's translations, then, during the early stages of writing Ulysses in Trieste and Zürich, he turned to Samuel Butler's and T. E. Shaw's translations, and finally in Paris he used Butcher and Lang's to incorporate its style and tone into his text. See Keri Elizabeth Ames, "Joyce's Aesthetic of the Double Negative and His Encounters with Homer's Odyssey," European Joyce Studies 16 (2005): 15-48, p.30.

${ }^{14}$ On line at: http://www.sacred-texts.com/cla/homer/greek/ody09.htm

${ }^{15}$ Butler's translation. 
textual details, Devecseri uses the same word semmirekellö once again: "semmirekello" szúrta ki drága szemem," that is, "good-for-nothing poked my eye out."

The rich Homeric reverberations conjured up by semmirekello make it particularly suitable for the horse's name. It is because of this name that Bloom falls victim to Lenehan's false accusation that he has won a pile of money by betting on a horse, which challenges the others' expectations about him - see the citizen's incredulous exclamation "- Is it that whiteeyed kaffir? [. . . ] that never backed a horse in anger in his life?" ( $U$ 12.1552) - which, in turn, leads to the wholesale questioning of his identity - his name, nationality, religion, virility - with the citizen concluding that he is "a wolf in sheep's clothing" ( $U$ 12.1666). In a roundabout way it also associates Bloom, called by Hynes a "bloody dark horse himself" ( $U$ 12.1558), with Odysseus. If such richly exfoliating intertextual reverberations cannot entirely make up for the partial rift in a crucial intratextual system of links, they can at least open up a path towards some joyous discovery.

\section{The Sweets of Honey}

Still concentrating on the restoration of verbal networks, my next example will demonstrate how at times the strategy of subtle shifting applied in the new translation has proved so effective that it has not only restored the intratextual play operating in the original, but made it more pronounced.

It is a well-known feature of Ulysses that it puts the best of memories to the test at the same time as it invites readers to play numerous mnemonic games. A crucial instance of this is the recurrence of the title and a few motifs of the adulterous book Bloom buys for his wife, Molly in "Wandering Rocks". The book's title Sweets of Sin and three of its motifs - the adulterous woman's "opulent curves" and "heaving embonpoint" and the ecstatic exclamation "For Raoul!" - function as delicate gateways between various dimensions of Joyce's adulterous text. The "opulent curves" and "heaving embonpoint" of the adulterous woman, apart from frequently appearing in connection with Molly, also come to function as shorthand expressions for the irresistibility of female seductive power, while the exclamation "For Raoul!" becomes emblematic of female passion in general. In addition to this, through these three motifs Molly and Boylan's adulterous liaison becomes associated with Bloom and Martha's adulterous epistolary flirtation, which suggests that only names change, roles do not. This is most strikingly demonstrated by the fact that the exclamation "For Raoul!" paradoxically associates Bloom with Boylan. 
When the title of the book explicitly appears in the text, there was not much left for us to do. Both Gáspár, who ingeniously translated the title Sweets of Sin as Bün méze (literally "Honey of Sin") and Szentkuthy, who wisely kept the title adding a definite article to it $A$ bün méze ("The Honey of Sin") consistently use it. Before steering into more problematic areas, however, it is worth dwelling a bit more (making a slight detour) on the merits of our translator-predecessors. Gáspár's solution for the title is also ingenious because it gives extra emphasis to an intratextual link, which partially compensates for the inevitable loss in the trans-cultural transfer of another crucial connection. Bün méze neatly rhymes with bün méhe ("womb of sin" $U$ 3.44), a phrase which encapsulates Stephen Dedalus's trauma caused by the paradox that his intellectual imagination, like that of Joyce, rebels against the dogmatic thinking of Catholicism, while his emotions and artistic imagination cannot escape from it. Even though one can easily detect a formal, structural connection between "sweets of sin" and "womb of sin" as well, in the Hungarian translation the association is much stronger as a result of the formal proximity between méhe and méze than in the case of "sweets" and "womb." The formal interplay between méhe and méze in the shadow of the idea of sin ("bün"), in turn, can conjure up something of the formal interplay between the English words "womb" and "tomb," which Stephen has a penchant to exploit (U 3.402, U 7.723 and $U$ 14.337), but which no Hungarian translation can fully render.

Having paid due homage to our predecessors, let us see now what tasks they have left for the later generations. With respect to two of the above mentioned three motifs of Sweets of Sin - "opulent curves" and "heaving embonpoint" - we had much more to do, since neither Gáspár nor Szentkuthy seemed to be aware that they keep recurring in the narrative. Not using the same phrases consistently they deprived the readers of the opportunity to play the mnemonic game readers of the original can enjoy. Here, however, I do not want to focus on how we restored these motifs, which we duly did, but on a textual place where Sweets of Sin looms large in the text even if there is no explicit reference to the book.

The scene in question is the climax of "Nausicaa", where the ecstatic soaring then swooning of language reflects how, thanks to the exhibited charms of Gerty MacDowell and some handiwork, Bloom manages to achieve temporary relief from the pressure accumulated during the day, and especially as a result of the altercations in Barney Kiernan's:

And then a rocket sprang and bang shot blind blank and O! then the Roman candle burst and it was like a sigh of $\mathrm{O}$ ! and everyone cried $\mathrm{O}$ ! $\mathrm{O}$ ! in raptures and it gushed out of it a stream of rain gold hair threads and they shed and ah! they were all greeny dewy stars falling with golden, $\mathrm{O}$ so lovely, $\mathrm{O}$, soft, sweet, soft! (U 13.736) 
Evidently translations should render on the level of language the bodily and spiritual excitement over the climactic explosion of the fireworks rocket, which also functions as a sublimated representation of Bloom's orgasm. Ideally, however, translations of the passage should also conjure up the adulterous book in Bloom's pocket, since, because of the most immediate context and because of the intricate intertwining of Catholic symbolism and erotic interplay in the chapter - in the course of which Bloom appears in Gerty's imagination as a sinner ( $U$ 13.433, $U$ 13.749), or rather as a man "more sinned against than sinning" $(U \text { 13.432) })^{16}-$ it is difficult not to hear the book's ironic echo in the last three swooning words - "O, soft, sweet, soft!"

In Gáspár's and Szentkuthy's translations this echo is totally missing. Gáspár's last three words "Oh milyen puha, édes, puha!" (297, emphasis added), and Szentkuthy's "Ó, de lágy és édes újra lágy!" (455, emphasis added $)^{17}$ do not contain the remotest hint at the adulterous book, its title or any of its motifs. Although the last three swooning words in the new translation - "Ó de puha, pihe, puha!"18 - are also devoid of such an echo, in contrast to the earlier translations, with a little bit of manouvering it sneaks back the potential link into the description of how the literal and metaphorical fireworks rocket explodes.

One of Joyce's verbal bravura in "Nausicaa" is that Bloom's orgasmic moment is dramatised by language. At the climactic point the sentence completely breaks through its grammatical boundaries, the text seems to reach a moment of jouissance: "and it gushed out of it a stream of rain gold hair threads" (emphasis added). Hungarian readers so far could sense none of this, could not even suspect that in the English original four, gently panting nouns stand beside each other without any grammatical organisation and without any punctuation, since both Hungarian translations drive the unruly parts of sentence back within the confines of grammar. Gáspár translates the above quoted fragment as "És hajszálfinom arany szikraesö zuhogott belöle," which literally translates into 'And from it gushed a golden shower of sparks as fine as hair,' while Szentkuthy translates it as "és aranyesö hajszálak sisteregtek mindenfelé," the literal translation of which is 'and golden rain hairs fizzed

${ }^{16}$ Also a King Lear echo (III.2 59-60) becoming a cliché by 1904, according to Gifford. See Don Gifford with Robert J. Seidman, Ulysses Annotated: Notes for James Joyces's Ulysses. 2nd. ed. (Berkeley and Los Angeles: U of Californi P, 1988).

${ }^{17}$ Gáspár translated the English words literally, while Szentkuthy chose to ignore the rhythm of the original by embellishing the three words. His solution translates back into: 'so soft and sweet, soft again.'

${ }^{18}$ The three swooing words in the new translation do not only follow the vowel sequence of the original - back-front-back - but also reproduce the alliteration. 
everywhere." ${ }^{19}$ It is worth noting here that Hungarian readers were not at a disadvantage in relation to readers of Ulysses in several other translations. As Senn demonstrated two decades ago, none of the German, Italian, French and Spanish translations he looked at dared to release the passage from "grammatical and semantic strait jackets in favour of a metamorphotic string of images." 20

The new Hungarian translation seeks to reproduce the verbal virtuosity of the original in a way that the passage can also become part of the intratextual play the last three swooning words inescapably disrupt: "és elötört belöle, áradt a fény haj méz víz" (emphasis added). Although the four one-syllable nouns standing without any grammatical organisation beside each other fény haj méz viz, with one exception - haj, "hair" - are not literal translations of the English nouns "rain gold hair threads," their choice was not unmotivated. "Rain" and viz ('water') are semantically close to each other, while fény ('light') and méz ('honey') can be associated with "gold." Only the meaning of "threads" disappers, but this does not seem to be a significant damage. The sound effect of "hair threads" is elegantly reproduced in méz viz, and the vowel-sequence of the Hungarian words reflects the vowel sequence in the English original: front-back-front-front. The insertion of the motif of méz ('honey') into the representation of the orgasmic moment disrupting linguistic norms, in turn, does not only restore but renders the subtle ironic play of the passage more emphatic.

\section{The Strange Case of Butterly and a Gravedigger}

Finally, I will concentrate on a crux that Senn has discussed at length to demonstrate the basic intranslatability of Ulysses: the challenging sentence in the opening chapter "- And going forth he met Butterly" ( $U$ 1.527), a Mulliganesque variation of the Gospel sentence "And going forth he wept bitterly" (Matt. 26:75). Looking at a French and four different German translations of this one sentence in the light of its functions and manifold potential reverberations in the original, Senn concludes that "inevitably translations are an essentially much more restricted happy huntingground for inquisitive minds in search of balanced interpretations." 21

\footnotetext{
${ }^{19}$ It must be acknowledged that both translations are quite poetical, mingling images of water and fire. The Hungarian word "aranyeső" (literally 'golden rain') in Szentkuthy's translation is particularly apt, since it is polysemic: its denotations include "fireworks," but also "laburnum," a bush with yellow flowers.

${ }^{20}$ Senn, (1984), p.35.

${ }^{21}$ Senn, (1984), p. 37.
} 
Senn's observation holds more than true for the existing two Hungarian translations as well. Gáspár does nothing more than transplant the sentence word by word into Hungarian: “- És menetközben találkozott Butterlyvel” (Hu U1 13). Szentkuthy “- És előremenvén látá Butterlyt" (Hu U2 22) does even less, since, for some obscure reason, it substitutes the act of "seeing" for that of "meeting." In contrast to the earlier version, however, it aims to render Mulligan's stilted diction. Despite this stylistic effort, the latter version evinces no more awareness of the biblical echo than the former. Obviously, such awareness may not necessarily yield more gratifying solutions, but in this particular case it is capable of doing so, since the Hungarian translations of the relevant Gospel sentence could lend themselves to a playful transformation that renders the Joycean sentence in Hungarian almost as happy huntingground for inquisitive minds in search of balanced interpretations as the original.

Before discussing what epiphanies a new Hungarian version would be capable of, however, let us look at what aspects of the sentence should ideally be preserved by the translator. As Senn has pointed out, it functions as an epitome of the whole of Ulysses, since it "imperfectly participates in two contexts: a tale of ordinary events in Ireland 1904, on which some large cultural prototype is superimposed." 22 On the one hand, the name Butterly looks like a good Irish name, so the sentence can be taken at face value, describing a meeting in "this Book of Meetings." On the other hand, the fact that it is "a slight variation of a Biblical matrix" embellishes it with all sorts of reverberations, so lucidly mapped by Senn that his train of thought is worth quoting in full:

The Gospel echo infuses the passage with irritant vigor. It metamorphoses. It changes an otherwise indistinct "he" [. . .] into a prominent disciple and saint, St. Peter, who was chosen to become the foundation of the Church - which is also so dominant in Joyce's Dublin. He is introduced into the book by the same process that led to his selection by Christ, accidents of language: "Thou art Peter, and upon this rock I will build. .." That this homonymous Peter was given the power of the keys adds theological resonance to Stephen's and Buck's wrangle about the key to the Martello tower; and this within an epic full of keys given up or forgotten, crossed, played upon verbally and pictorially. In the Gospel Peter's repentant weeping is immediately preceded by his discovery, it was his language: "thy speech bewrayed thee," or "thy speech doth discover thee" (Matt. 26:73). ${ }^{23}$

In Senn's opinion, it is as damaging to disregard the Dublin surface as to deprive the sentence of its biblical reverberations, yet a transla-

\footnotetext{
${ }^{22}$ Ibid.

${ }^{23}$ Ibid.
}

Scientia Traductionis, n.8, 2010 
tion cannot have it both ways. If a translator feels totally inadequate by now, Senn's finishing stroke is still to come:

The problem is not alone how much outside reality or Bible 'content' is being caught, but the enabling of that mysterious process of identification that Joyce conjugates so polytropically. "Butterly" is an early Odyssean disguise, or fake identity that we can metamorphose into a histrionic adverb (well suited, by the way, to Stephen, who is multiply characterized by bitterness).,24

To pile on one more dimension, it could also be noted that if the adverb "bitterly" is well suited to Stephen, "Butterly," as name and adverb, is no less well suited to Mulligan, who is repeatedly characterised by literal and metaphorical butterness. Butterly Mulligan, thickly buttering his bread on both sides ( $U$ 1.447), or plastering butter on his scone ( $U$ 10.1086), unlike a translator or Stephen, can have his cake and eat it. But what is the bitter translator to do, having realised that she cannot do the same? Obviously, she does not rest in silence, but thinks, ponders and cogitates how to convey in her own language the intricacies of the original. In the end she arrives at the following solution: "És kimenvén onnan, kesergő sírásóra akadt" - a slight variation on the Gospel matrix "És kimenvén onnan, keserves sírásra fakadt" 25 - which roughly translates into "And going forth, he came across a grieving gravedigger." The damaging aspect of such a solution is that Butterly - and with him Dublin reality, Odyssean disguise and butterness - got lost in the abysses of interlingual space.

For this heavy loss, however, there is rich recompense. The formal play with the Gospel sentence is as witty as in the original: Keserves becomes kesergö, both derivatives of the same root expressing bitterness, the former being an adjective, the latter a present participle ('grieving'); sírásra ('into tears') metamorphoses into sírásóra ('gravedigger' with a sublative suffix); and fakadt ('burst into') turns into akadt ('came across'). The rhythm of the Gospel sentence is so closely followed that the echo readily lends itself to the discerning ear and eye, which makes the sentence capable of releasing almost the same immediate effect as the original. It also bespeaks of a meeting of sorts in this "Book of Meetings," even if not necessarily in a Dublin context. A meeting with a gravedigger, however, thematically fits into the context of the opening chapter, where bitter Stephen is explicitly identified by Mulligan, or rather by his aunt, as

\footnotetext{
${ }^{24}$ Ibid.

${ }^{25}$ This is actually an amalgamation of two different translations. It fuses the first half of the archaic Protestant version: "És kimenvén onnan, keservesen síra" (Károli’s Bible, the first full Hungarian Bible translation), and the second half of the currently used Catholic translation: "És kiment, és keserves sírásra fakadt" (St Stephen Bible Society).
} 
his mother's gravedigger ( $U$ 1.88). Stephen's compulsively returning nightmare about his mother likewise suggests some unconscious fear on his part that Mulligan is right after all, since he did not abide his dying mother's desperate plea to kneel down and pray for her soul. Such considerations also conjure up the cause of Saint Peter's bitter weeping: his betrayal of Christ because of his lapse of faith.

In addition to its thematic potentials, the image of a gravedigger in the Hungarian version also enables Mulligan's utterance to participate in a more complex intertextual and stylistic game than in the original. Mulligan's Butterly sentence is sandwiched between his more evident Gospel-echo pronouncement - "Mulligan is stripped of his garments" ( $U$ $1.510)$ - and Haines's inquiry about Stephen's "idea of Hamlet" ( $U$ 1.545), being roughly halfway between the two. That Stephen has some idea of Hamlet, Haines first hears about from Mulligan, shortly before he embarks upon his biblical jesting. In this textual context the image of the gravedigger inescapably conjures up Shakespeare's text, which imbues the otherwise unsurprising image of a kesergö sirásó ('grieving gravedigger') with an ambivalent, paradoxical air. Since gravediggers function in Hamlet as perpetrators of comic relief, the phrase is capable of becoming an oxymoron. Thus, the Protean, dynamic potentials of this phrase can epitomise the dynamics of "corrective unrest" operating in Ulysses, as Senn's writings so well demonstrate. Furthermore, owing to the image of the gravedigger - adding a Hamletian overtone to a Gospel echo - the Hungarian sentence performs a superimposition of sorts: not cultural prototype on reality, but cultural prototype on cultural prototype, an imperfect compensation, no doubt, but one that emulates another equally characteristic feature of Ulysses.

The intertextual potentials of the Hungarian version of Mulligan's utterance within "Telemachus" are further supplemented by its ability to preserve or even play up an intratextual link between "Telemachus" and "Scylla and Charybdis": Mulligan's utterance seems to proleptically demonstrate the conclusion of Stephen's Hamlet theory. To clarify my point it is worth quoting the relevant passage from Stephen's conclusion in full:

He found in the world without as actual what was in his world within as possible. Maeterlinck says: If Socrates leave his house today he will find the sage seated on his doorstep. If Judas go forth tonight it is to Judas his steps will tend. Every life is many days, day after day. We walk through ourselves, meeting robbers, ghosts, giants, old men, young men, wives, widows, brothers-in-love, but always meeting ourselves. (U 9.1041-46) 
Although the "he" who meets Butterly in Mulligan's utterance in "Telemachus" is indistinct, in the wake of Mulligan's previous Gospelecho utterance, where he uses third person singular to describe his own actions, "Mulligan is stripped of his garments" $(U 1.510)$ it can be read as signifying Mulligan himself. In the light of our above considerations of the butterness of Mulligan, on a symbolic level, Mulligan's sentence describes Mulligan meeting himself. If such a reading seems far-fetched, it is worth noting the verb Stephen uses to describe Judas: "If Judas go forth tonight" seems to counterpart Mulligan's going forth in the early morning, the former implying and the latter echoing the theme of betrayal. That Mulligan meets Butterly, not Mulligan is echoed in Socrates meeting the sage, not Socrates in Stephen's paraphrase of Maeterlinck.

If such an intratextual link can be discovered in the original, the Hamletian image of a gravedigger in the Hungarian version can make it even more pronounced. Since the indistinct "he" in Mulligan's sentence might as well refer to Stephen as to Mulligan, the Hungarian version can also function as a portal to Stephen's Hamlet theory, with the overtones of betrayal preserved in full force.

My aim in these detailed discussions of the translation of minuscule verbal units in a gigantic text has not been to prove the impossible that a translation of Ulysses can be as ingenious as Joyce's original - but to demonstrate that not every particle of a translation needs to be less capable of an epiphany than those of the original. The question, of course, remains open whether there will ever be a Hungarian reader who will read any of these particles with the creative cooperation they potentially allow. This is not the translator's concern though. Knowing that a textual item could, if a reader would, is all one needs to know.

\author{
Marianna Gula \\ mariannagula@lycos.com \\ University of Debrecen, Hungary
}

Scientia Traductionis, n.8, 2010 